\title{
Lack of Population Structure in Coriander Populations Based on SDS (Seed Storage Protein) Page Analysis
}

\author{
Gülsüm Yaldiz ${ }^{1 *}$, Muhammad Sameeullah $^{2}$, Mahmut Çamlıca ${ }^{1}$, Faheem Shehzad Baloch ${ }^{1}$ \\ ${ }^{1}$ Depatrtment of Field Crops, Faculty of Agricultural and Natural Sciences, Abant İzzet baysal University, 14030 Bolu, Turkey \\ ${ }^{2}$ Department of Horticulture, Faculty of Agricultural and Natural Sciences, Abant Izzet Baysal University, 14030 Bolu, Turkey \\ A R T I C L E I N F O \\ Article history: \\ Received 23 April 2016 \\ Accepted 23 June 2016 \\ Available online, ISSN: $2148-127 \mathrm{X}$

\section{Keywords} \\ Coriander \\ Seed storage protein \\ Genetic diversity \\ Population structure \begin{abstract}
A B S T R A C T
Genetic variation is prerequisite for plant breeding. Nothing information existed in the literature for available diversity of Coriander accession in Turkey. Plant breeding activities are negligible in Turkey. So in order to start effective plant breeding program in Turkey, information on the available genetic diversity is viable. Therefore we planned to study the genetic variation and population structure of 29 Coriander accessions by seed storage protein (SDS). SDS analysis elaborated the lack of population structure and genetic bottleneck in the Coriander accessions in Turkey. Based on the results of this study, it was clear that sampling strategy was not appropriate and plant introduction should be made from different sources and diverse genotypes should be used as parents to initialize the effective Turkish Coriander breeding program.
\end{abstract}

Plant breeding

${ }^{*}$ Corresponding Author:

E-mail: g.yaldiz@hotmail.com

\section{Introduction}

Coriandrum sativum is known as with many different names such as coriander cilantro, Arab parsley, Chinese parsley, Dhania, etc. Coriander is among most widely used medicinal plant, possessing nutritional as well as medicinal properties. Coriander is an annual spice herb that belongs to the family of Umbelliferae/Apiaceae. Together with seven other genera, it is among 21 species of tribe Coriandreae W. Koch, which is included in subfamily Apioideae (Szujkô-Lacza, 1994; Diederichsen, 1996). The genus Coriandrum has only two species: $C$. sativum L., which is the cultivated coriander. The basic chromosome number of the genus Coriandrum is $\mathrm{x}=11$, and $C$. sativum $\mathrm{L}$. is a diploid with $2 \mathrm{n}=22$ (Darlington and Wylie, 1955). It is widely used in classical medicine, such as in the treatment of digestive disorders, diseases of the respiratory and urinary systems, relief of anxiety and insomnia, in allergies, amoebic dysentery, burns, cough, cystitis, dizziness, edema, hay fever, headache, hemorrhoids, rash, urethritis, urinary tract infection, urticaria, and vomiting (Duke, 1997; Emam ghoreishi et al., 2005; PDR-HM, 2007; Agarwal and Kunnumakkara, 2009). Coriander is widely cultivated in many countries like Russia, Hungary, England, France, Poland, Holland, Egypt, India, Pakistan, Turkey, etc. Coriander is mentioned by ancient sources nearly 3,800 years ago (Szujkô-Lacza, 1994), and Purseglove et al. (1981) tentatively established the eastern Mediterranean region as its center of origin. Little is known about the origin and domestication of coriender. However some previous researchers mentioned "Anatolian Plateau" its center of origin and domestication (Kan and Ipek, 2004). Its wild relative, C. tordylium (Fenzl) Bornm., is native to Turkey (Davis, 1972); there are not evidences for domestication of $C$. sativum $\mathrm{L}$. from $C$. tordylium.

It is grown on small scale in Anatolia. It is cultivated in different provinces of Turkey as medicinal plants such Ankara, Konya and Eskişehir. In last recent years, the export of coriander plant to foreign industries increased in Turkey, and due to this it is getting popularity. Two primary products obtained from the plant are fresh green herb and the spice seed. Herb is a perishable product widely used in several cuisines in Asia, the Middle East, and Central and South America. The entire plant is used in making chutneys and sauces green parts of coriander is used in some countries with name of "Chinese parsley", however main part of the plant is its seeds used in many different ways. For example, its seeds in whole in or grinded form used to give aroma in many products such in sweets, meat and milk products as well as in alcoholic beverages. Linalool, which is the main components of its oil used in perfumes and many cosmetics products.

For effective breeding program and germplasm management, the study of genetic diversity has received much attention in the last two decades (Baloch et al., 2015). Both variation in phenotype and genotype have been exploited to characterize and manage genetic diversity in germplasm collection of various plant species. Morphological traits and molecular markers are frequently used to study genetic diversity, to develop conservation strategies, to facilitate their management and 
to development plant genetic resources. Until now, very few reports investigated the level of genetic variation among the accessions of coriander. Coriander is one of the most important medicinal plant however grown on very small scale, and is one of the most neglected crops worldwide and is considered an "orphan crop". Therefore, there is a dire need to study and characterize the coriander germplasm. In the available studies some authors have determined variability in different coriander germplasm using AFLP markers (Lopez et al. 2008) and statistical tools to analyze 15 morphological and agronomic characters ( Mengesha and Alemaw, 2010).

Pareek et al. (2011) studied the genetic diversity of 10 Indian coriander varieties using RAPD markers. Singh et al., (2012) investigated the extent of variability among 22 Indian varieties of coriander using phenotypic and RAPD markers. Abou El-Nasr et al. (2013) studied the variability using essential oil composition and ISSR molecular markers among 10 coriander genotypes selected from three cultivars from Egypt. Recently, Fufa (2013) studied the genetic divergence of 25 land races using principal component and cluster analysis based on 8 characters. To our best of knowledge, we did not find any study about the available diversity and structure of coriander population in Turkey. This is first report to study the diversity of coriander accessions in Turkey based on seed storage protein. Now we are collecting coriander germplasm from different countries to characterize and to start a breeding program in Turkey. Genetic variations are an essential prerequisite factor in any breeding program to identify potential parents for hybridization and to obtain high yielding varieties to start an effective breeding program, there is need to characterize the available germplasm and have information about population structure, degree of heterogeneity.

We are trying to initiate local coriander breeding program and trying to introduce a coriander as alternative crop to the farmer. To select a parents, we did not have any information. Therefore our aim was here to collect some population of coriander and check the available diversity present in the 24 populations of coriander representing different provinces of Turkey including one population from each of India, Georgia (Batumi), Iraq (Kirkuk) and 2 populations from Pakistan. To check the population structure of 25 coriander accession from Turkey and other countries was also other one of our aims.

\section{Materials and Methods}

Seeds of total twenty nine genotypes of coriander (Coriandrum sativum L.) including 24 obtained from different sources in Turkey, one from each of India, Georgia (Batumi), Iraq (Kirkuk) and two from Pakistan. Detailed information about the genotypes used in this study is briefly illustrated in the Table 1 .

Table 1 Population name, collection site and their coordinates of 29 Coriander populations collected from different areas

\begin{tabular}{|c|c|c|c|}
\hline No & Coriandrum Population/Culture & Place of Collection & Coordinates \\
\hline 1 & Gamze 2012 & Samsun & $41^{\circ} 17^{\prime} 25^{\prime \prime} \mathrm{N} 36^{\circ} 20^{\prime} 01^{\prime \prime} \mathrm{E}$ \\
\hline 2 & Pelmus & Samsun & $39^{\circ} 56^{\prime} \mathrm{N} 32^{\circ} 52^{\prime} \mathrm{E}$ \\
\hline 3 & Arslan & Ankara & $39^{\circ} 08^{\prime} \mathrm{N} 34^{\circ} 10^{\prime} \mathrm{E}$ \\
\hline 4 & Kırşehir & Kırşehir & $37^{\circ} 25^{\prime} 30^{\prime \prime} \mathrm{N} 29^{\circ} 21^{\prime} 14^{\prime \prime} \mathrm{E}$ \\
\hline 5 & Denizli-2 & Denizli- Acipayam & $39^{\circ} 56^{\prime} 45^{\prime \prime} \mathrm{N} 41^{\circ} 6^{\prime} 19^{\prime \prime} \mathrm{E}$ \\
\hline 6 & Erzurum & Erzurum-Aziziye & $37^{\circ} 18^{\prime} 40^{\prime \prime} \mathrm{N}, 29^{\circ} 46^{\prime} 28^{\prime \prime} \mathrm{E}$ \\
\hline 7 & Burdur & Burdur-Tefenni köyü & $39^{\circ} 34^{\prime} \mathrm{N} 32^{\circ} 6^{\prime} \mathrm{E}$ \\
\hline 8 & Polatl1-Big-Kernel & Ankara-polatlı & $30^{\circ} 11^{\prime} 52^{\prime \prime} \mathrm{N} 71^{\circ} 28^{\prime} 11^{\prime \prime} \mathrm{E}$ \\
\hline 9 & Multan & Multan & $39^{\circ} 25^{\prime} 52^{\prime \prime} \mathrm{N} 32^{\circ} 29^{\prime} 44^{\prime \prime} \mathrm{E}$ \\
\hline 10 & Small Kernel & Ankara-Haymana & $35^{\circ} 28^{\prime} 0^{\prime \prime} \mathrm{N}, 44^{\circ} 19^{\prime} 0^{\prime \prime} \mathrm{E}$ \\
\hline 11 & Kirkuk-F2 & Kirkuk & $41^{\circ} 31^{\prime} \mathrm{N} 35^{\circ} 35^{\prime} \mathrm{E}$ \\
\hline 12 & Erbaa & Samsun -Tekkekoy & $41^{\circ} 17^{\prime} 25^{\prime \prime} \mathrm{N} 36^{\circ} 20^{\prime} 01^{\prime \prime} \mathrm{E}$ \\
\hline 13 & Kudret-K & Samsun & $18^{\circ} 58^{\prime} 30^{\prime \prime} \mathrm{N} 72^{\circ} 49^{\prime} 33^{\prime \prime} \mathrm{E}$ \\
\hline 14 & India-14 & India & $39^{\circ} 56^{\prime} \mathrm{N} 32^{\circ} 52^{\prime} \mathrm{E}$ \\
\hline 15 & Gurbuz & Ankara & $9^{\circ} 54^{\prime} 35^{\prime \prime} \mathrm{N} 41^{\circ} 16^{\prime} 32^{\prime \prime} \mathrm{E}$ \\
\hline 16 & Erzurum-Small-Kernel & Erzurum & $37^{\circ} 25^{\prime} 26^{\prime \prime} \mathrm{N} 30^{\circ} 05^{\prime} 04^{\prime \prime} \mathrm{E}$ \\
\hline 17 & Burdur & Burdur & $37^{\circ} 54^{\prime} 45^{\prime \prime} \mathrm{N} 28^{\circ} 19^{\prime} 14^{\prime \prime} \mathrm{E}$ \\
\hline 18 & Nazilli & Nazilli & $40^{\circ} 28^{\prime} \mathrm{N} 32^{\circ} 39^{\prime} \mathrm{E}$ \\
\hline 19 & Small Kernel & Kizılcahamam & $37^{\circ} 18^{\prime} 51.37^{\prime \prime} \mathrm{N} 40^{\circ} 44^{\prime} 19.30^{\prime \prime} \mathrm{E}$ \\
\hline 20 & Mardin-Big-Kernel & Mardin & $37^{\circ} 10^{\prime} 54^{\prime \prime} \mathrm{N} 30^{\circ} 56^{\prime} 00^{\prime \prime} \mathrm{E}$ \\
\hline 21 & Antalya & Antalya & $41^{\circ} 08^{\prime} \mathrm{N} 041^{\circ} 51^{\prime} \mathrm{E}$ \\
\hline 22 & Artvin & Artvin & $41^{\circ} 16^{\prime} 41.2710091^{\prime \prime} \mathrm{N} 41^{\circ} 8^{\prime} 41.1440134^{\prime \prime} \mathrm{E}$ \\
\hline 23 & Rize Findıklı & Rize Fındıklı & $41^{\circ} 39^{\prime} \mathrm{N} 41^{\circ} 39^{\prime} \mathrm{E}$ \\
\hline 24 & Batumi & Batumi & $37^{\circ} 10^{\prime} \mathrm{N} 33^{\circ} 12^{\prime} \mathrm{E}$ \\
\hline 25 & Karaman & Karaman & $33^{\circ} 43^{\prime} \mathrm{N} 73^{\circ} 04^{\prime} \mathrm{E}$ \\
\hline 26 & Islamabad & Islamabad & $37^{\circ} 44^{\prime} 36^{\prime \prime} \mathrm{N} 29^{\circ} 17^{\prime} 29^{\prime \prime} \mathrm{E}$ \\
\hline 27 & Denizli & Denizli & $40^{\circ} 14^{\prime} 19^{\prime \prime} \mathrm{N} 33^{\circ} 1^{\prime} 59^{\prime \prime} \mathrm{E}$ \\
\hline 28 & Small Kernel & Ankara-Çubuk & $41^{\circ} 17^{\prime} 25^{\prime \prime} \mathrm{N} 36^{\circ} 20^{\prime} 01^{\prime \prime} \mathrm{E}$ \\
\hline 29 & Gamze 2 & Samsun & $41^{\circ} 17^{\prime} 25^{\prime \prime} \mathrm{N}, 36^{\circ} 20^{\prime} 01^{\prime \prime} \mathrm{E}$ \\
\hline
\end{tabular}




\section{Buffers and Reagents}

High quality chemicals and reagents were used for the preparation of extraction buffer, staining solution and protein marker to avoid contamination of proteinase. The chemicals were purchased from Merck of highest purity. Extraction buffer was prepared with modifications (Ghafoor et al. 2002). Briefly, $62.5 \mathrm{mM}$ Tris- $\mathrm{HCl}$ (pH 6.8), $2 \%$ SDS, $10 \mathrm{mM}$ DTT, $10 \%$ glycerol and 5M urea making the final concentrations of buffer. Sterilized micro centrifuge tubes were used to collect seed flour and extraction of proteins.

\section{Protein extraction and SDS-PAGE analysis}

Proteins were extracted from fine ground seed flour (10 mg) using $400 \mu \mathrm{L}$ extraction buffer. After thoroughly mixing of seed flour with extraction buffer micro centrifuge tubes were warmed on thermoplate at $40^{\circ} \mathrm{C}$ for $1 \mathrm{~h}$. Homogenates were vortexed and then centrifuged at 13000 RPM for 5 minutes. Soluble proteins as supernatant were transferred to new sterile micro centrifuge tubes and stored at $4^{\circ} \mathrm{C}$. Next day, $10 \mu \mathrm{L}$ of supernatant was taken of each genotype and mixed with $10 \mu \mathrm{L}$ of $2 \mathrm{X}$ boromophenol blue loading dye and heated at $95^{\circ} \mathrm{C}$ for 5 minutes. SDS-PAGE was carried following the procedure described by (Laemmli 1970). Briefly, 15 $\mu \mathrm{L}$ of denatured proteins were loaded into SDS-PAGE with $4.5 \%$ stacking gel and $15 \%$ resolving gel. The proteins were electrophoresed at $4^{\circ} \mathrm{C}$ for $4 \mathrm{~h}$ at constant current of 230 voltage using electrophoresis system P9DS (Thermo scientific, USA). The gels were stained with Bio-Safe Comassie stain (Bio-Rad, Hercules, CA, USA) following the manufacturer instructions.

\section{Data Analyses}

Scoring of the data was performed by counting the presence or absence of bands within a protein marker bands of specific mass (KDa). Genetic distance coefficients among accessions was estimated according to jaccard index (Jaccard, 1987) for pairwise comparison based on the proportion of shared bands produced by all primers. Neighbor Joining analysis were constructed using the computer software program ' $R$ '.

\section{Population Structure Analysis}

The population structure and the inference of admixture ancestry were assessed with a model-based clustering method implemented in STRUCTURE 2.1. In the structure program, numbers of populations $(\mathrm{K})$ were assumed; each was characterized by a set of allele frequencies at each locus. The numbers of populations (K) selected were 1-10 based on models characterized by admixed and correlated allele frequencies. Different $\mathrm{K}$ values were tested (from 1 to 10 ), with ten independent runs for each value [50,000 Burn-in periods and 150,000 Monte Carlo Markov Chain (MCMC), Evanno et al. (2005)]. The change in the log probability of data between successive $\mathrm{K}$ values obtained from the STRUCTURE output was used to determine the true number of subpopulations (Figure 1).

\section{Results}

When the total seed proteins of the studied coriander accessions were separated by SDS-PAGE under reducing conditions, the patterns of the bands obtained were different for all the evaluated accessions, except the Kudret 2012 and Rize, Findikli accessions with identical electrophoretic patterns collected from Samsun and Rize . The number of protein bands in the electrophoregram of the studied coriander accessions ranged from 10 to 17 bands with a total of 17 bands and molecular weights ranged from 50 to $1170 \mathrm{kDa}$ were detected in 25 coriander accession in seed storage protein analysis (SDS). Of these 17 bands, 5 showed polymorphism whereas rest of the bands showed monomorphic banding pattern.

A pairwise genetic distance (GDj) matrix among twenty five coriander accessions was calculated using Jaccard's coefficient using $\mathrm{R}$ statistical software. Maximum genetic distance was 0.636 among accession of Kudret 2012-Pelmus and Kudret 2012-Rize Findikl1, where the minimum genetic distance of 0,091was ErbaaDenizli-2. Most of the populations were same in genetic structure such small kernel, India14, Denizli1, Burdurtefenni-beykoy were genetically similar. Similarly, Antalya,, Nazili2014, Batum, Artvin and karaman, Ankara and kirşehir also clustered under same group We also noted that most of the genetic distance coeeficient was closed to 0.091 . This indicated the close relationships between the evaluated accessions, though they are collected from different geographical provinces. Neighbor joining clustering was conducted to see the pattern of variations among the 25 coriander accessions. Neighbor joining tree was computed from Jaccard genetic distance coefficient and was shown in Figure 2. The neighbor joining analysis splitted all accessions into two main groups as A and B. Group B again divided in two four different groups.

The principle component analysis revealed that electrophoretic data of the total seed proteins of 25 coriander accessions showed that first two principle component of the seed protein contents contribute to $79.6 \%$ of the variations. All coriander accessions were separated in the first two principle component analysis (Figure 3).

In the STRUCTURE analysis, the number of groups (K) varied from 1 to 10 . Using the DK criteria from Evanno et al. (2005), it was observed that the two different gene pools were identified at preliminary level among 138 pea accessions (Figure 4a). The estimated delta $\mathrm{K}$ value was 613.42 for 25 coriander accessions, which represent two subpopulations. Further subgroups were formed at the value of $K=5$ (Figure $4 \mathrm{~b}$ ). All two $K$ values showed that Admixture of the genotypes was observed in the confirming the PCA and neighbor joining analysis. All accessions showed admixture of two-five populations as revealed in the structure analysis at $\mathrm{K}=2$, $\mathrm{K}=5$ (Figure 4a, 4b). 


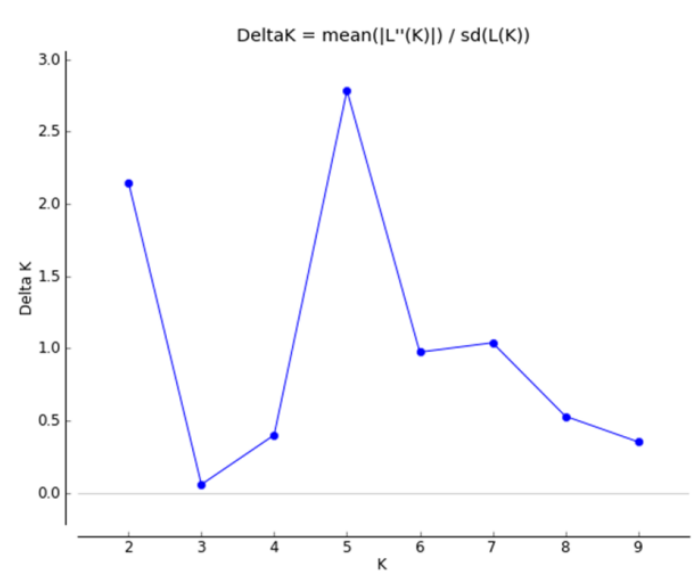

Figure 1 Estimated number of $\mathrm{K}$ for the population structure analysis of Coriander

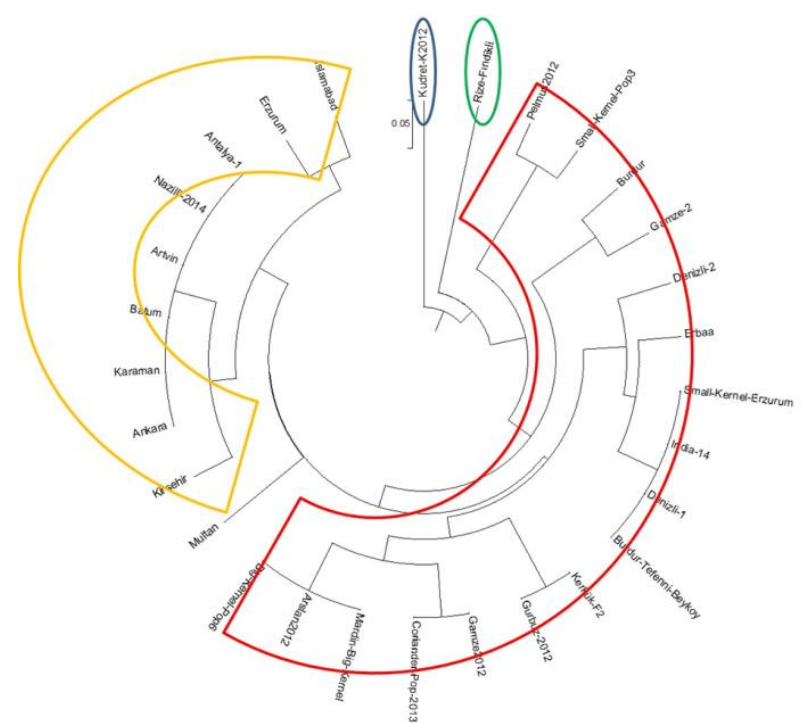

Figure 2 Neighbor joining clustering analysis of 29 Coriander populations

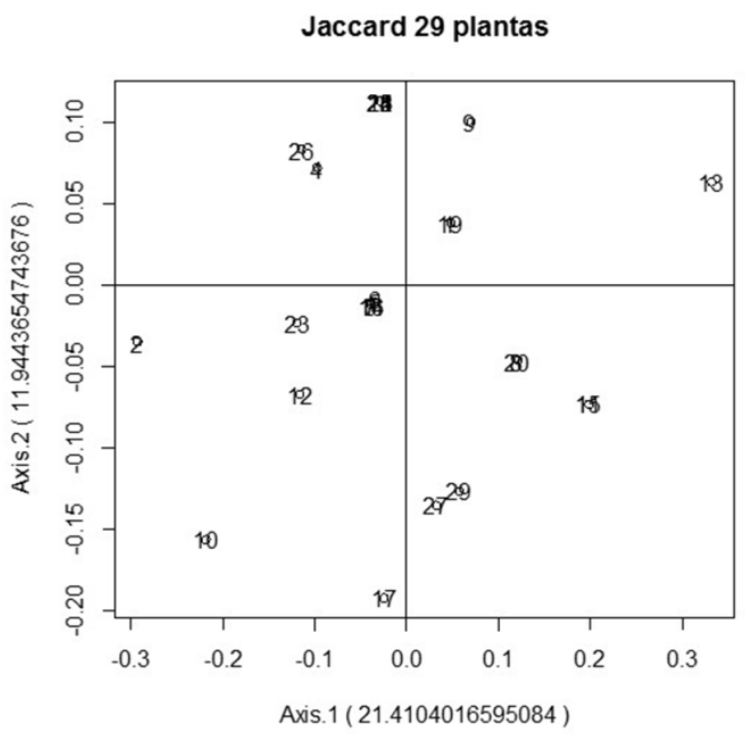

Figure 3 Principle component analysis (PCA) of 29 Coriander populations

\section{Discussion}

Variety identification of coriander is still based on morphological characters in Turkey as well in the world. Most morphological characters for variety identification are multigene and are affected by environmental conditions. In addition, different developmental stages of coriander are required to assess these morphological traits making the coriander variety identification timeconsuming, less suitable for expeditious results, and ineffective for large number of genotypes. For many years, cultivars with narrow morphological deviations were evaluated with reference to yield and quality using traditional field plot techniques. However, the identification with this technique is tedious and time consuming (Sammour 2014). Seed storage protein analysis using SDS-PAGE is considered as an important tool to elucidate taxonomic difference among plants as seed proteins are comparatively less affected by environmental factors and remain stable. Different researcher from different countries have used this technique as a strong tool to document information on the origin, taxonomic affinities, cultivars identification and evolution of cultivated plants (Khurshid and Rabbani, 2012).

Although total seed protein profiling revealed no significant intra-specific genetic diversity or genotype specific bands, some accessions showed remarkable polymorphism on the basis of protein banding pattern. In the last decades, characterization of coriander genotypes was done using morphological traits and using DNA molecular markers such a RAPD, AFLP and others etc. from different parts of the world (López et al, 2007) However, with best of our knowledge, we did not find any genetic diversity study of coriander genotypes in Turkey. Therefore, we aimed here to characterize the coriander accessions obtained from different sources in Turkey and other countries to see the available diversity harbored by the population.

This research was performed in order to characterize and study the diversity and relationships among coriander genotypes using seed storage proteins and to use this information for breeding superior hybrids or varieties. According to neighbor joining analysis, two accessions Kudret 2012 and Rize, Findikli were clearly discriminated from the rest of genotypes and showed highest diversity. Cluster splitted all accessions in two main groups as A and B. Group A consisted of only one cultivar Kudret 2012. The group B again divided into two main groups, B1 and B2. Again Group B1 consisted only one cultivar Rize-findikli and group B2 consisted of 17 accessions. Group $\mathrm{C}$ consisted of 10 accessions. In group $\mathrm{C}$, Pakistani accessions, "MULTAN" was most differentiated. In neighbor joining analysis, India-14, Denizli, Burdur and Small Kernel Erzurum showed 100\% similarity with each other. Similarly in group C, Ankara, Karaman, Batum, Artvin, Nazilli, Antalya, Erzurum and Islamabad showed highest similarity.

In order to get clearer picture, principal component analysis (PCA) was done to see the pattern of variation. 
When we see the at the principle component analysis graph (Figure 4), we observe that grouping of the coriander accessions was according to its geographical origin as depicted in cluster analysis (Figure 4).

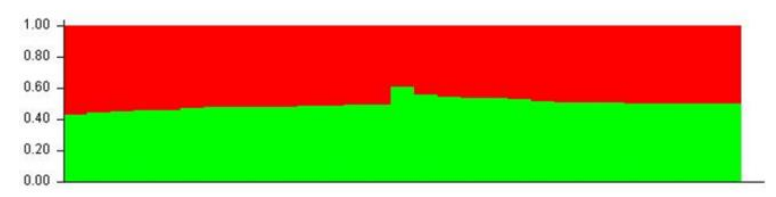

Figure 4(a).

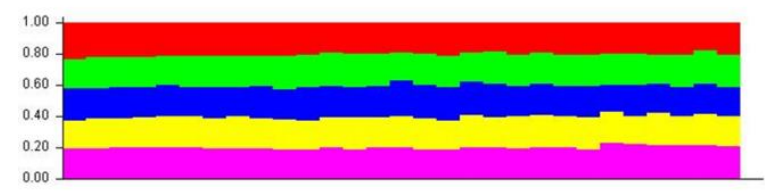

Figure 4(b).

Figure 4 Population structure of Coriander germplasm (a) Estimated population structure at $\mathrm{K}=2$ (b) Estimated population structure at $\mathrm{K}=5$.

The Neighbor Joining analysis and Principal coordinate analysis based on the seed storage protein data failed to cluster all coriander accessions on the basis of their provenance. Coriander accessions did not show grouping according to their place of origin. Interestingly, geographically close population can be genetically highly distant whereas geographically distant population can, in cases, more genetically similar. For instance, the populations from Kudret 2012-Pelmus and Kudret 2012Rize Findiklı showed the highest genetic distance, whereas Erbaa-Denizli-2, Erzurum, Burdur, India 14, Erzurum Small Kernel, Kırşehir-Nazilli, Antalya, Artvin, Batumi, Karaman, Small Kernel, Islamabad-Erzurum, Nazilli, Antalya, Artvin and Denizli-Rize, Karaman, Islamabad had the lowest genetic distance. Reasons for the mixing of different accession from different geographical background under same clusters might be due to selection of unconscious favorable alleles by farmers with better adaptation to local agro climatic conditions and exchange of seeds by farmers from distant regions. Migration of seeds among regions, followed by mixing and introgression with preexisting germplasm, could be another reason. Throughout history, Turkey has been a junction of cultures between Europe, Asia and Africa. The traders and migrators might also played the role in spreading the coriander genetic resources because it always appeal various medicinal uses in the past. The mixing of the genetic resources in Turkey seems most probable due to geographical position of Turkey. Similar results have been documented among landraces of different crops such chickpea, lentil, maize, pea from Turkey (Özer et al., 2012; Toklu et al., 2008; Cömertpay et al., 2012; Baloch et al., 2015). The genetically diverse groups identified in this study can be used to derive parental lines to initiate breeding program. The information revealed in neighbor net joining analysis may be useful in designing a breeding program. An increase in the genetic diversity of future varieties worldwide can be achieved by crossing the diverse parents. However there is need to screen this germplasm using DNA molecular markers to confirm the diversity and to start a solid breeding program. There is also urgent need to introduce diverse introduction lines from different countries particularly from the area of coriander biodiversity.

The results of the STRUCTURE analysis showed that the optimal $\mathrm{K}$ value was 2 and 5 , yet the assignment results from $\mathrm{K}=2$ and $\mathrm{K}=5$ appear to be unrelated to geographic distance. Subpopulations were assembled by groupings accessions with a membership probability higher than 0.80 , while accessions with a lower membership probability were assigned to a mixed groups. Structure analysis showed admixture of all coriander accessions and exhibited very weak population structure (Figure 4a, 4b).

This again exhibited lack of proper breeding program of coriander genotypes and lack of proper conservation of the coriander genetic resources. Despite of their medical uses and traditional implementation, lack of breeding program of medicinal plants is evident throughout the world. Therefore such type of crops referred as "ORPHAN CROPS". Here we started to gain information about the genetic diversity and population structure of available coriander germplasm in Turkey and we are going to collect the coriander from whole geographical regions of Turkey and to initiate breeding program.

In conclusion, the present study used the seed storage proteins to generate pre-breeding data that can potentially be applied for selection of appropriate parents to introduce greater genetic variation in coriander breeding programs and help the breeders of Turkey. The data also showed that sampling strategy was not appropriate. Based on our results, a change in sampling strategy must be followed particularly samples should be collected from natural habitat of coriander and in general samples should be collected from its widely grown areas at priority: more populations with less individuals, rather than more individuals within populations, should be collected to appraise and safeguard the genetic diversity and to make its conservation strategies.

\section{References}

Agarwal BB, Kunnumakkara KB. 2009. Potential therapeutic effects of curcumin, the anti-inflammatory agent, against neurodegenerative, cardiovascular, pulmonary, metabolic, autoimmune and neoplastic diseases. Int. J. Biochem. Cell Biol. 41(1): 40-59.

Abou El-Nasr THS, Ibrahim MM, Aboud KA and El-Enany Magda AM. 2013. Assessment of genetic variability for three coriander (coriandrum sativum 1.) cultivars grown in egypt, using morphological characters, essential oil composition and ISSR Markers. World Applied Sciences Journal 25 (6): 839-849.

Baloch FS, Shah MA, Khan AI, Awan FS, Sadaqat HA, Bahadur S, Rasheedet A. 2015.Genetic Diversity of Some Tomato Cultivars and Breeding Lines Commonly Used in Pakistani Breeding Program. Turkish Journal of Agriculture - Food Science and Technology, 3(3): 126-132. 
Cömertpay G, Baloch FS, Kilian B, Ülger AC, Özkan H. 2012. Diversity assessment of Turkish maize landraces based on fluorescent labelled SSR markers. Plant Molecular Biology Reporter, vol. 30, pp. 261-274.

Darlington CD, Wylie AP. 1955. Chromosome atlas of flowering plants. George Allen and Unwin Ltd. London.

Davis PH. 1972. Flora of Turkey and the East Aegean Islands. Volume 4. Edinburgh University Press. Edinburgh, Great Britain.

Diederichsen A. 1996. Coriander. Promoting the conservation and use of underutilized and neglected crops 3. International Plant Genetic Resources Institute (IPGRI), Rome, Italy.

Duke JA. 1997. Green Pharmacy: New Discoveries in Herbal Remedies for Common Diseases and Conditions from the World's Foremost Authority on Healing Herbs.. Emmaus, Pennsylvania: Rodale Press, ISBN 0-87596-316-1.

Emamghoreishi M, Khasaki M and Aazam MF. 2005. C. sativum: Evaluation of its anxiolytic effect in the elevated plus-maze. J. Ethnopharmacol; 96: 365-70.

Evanno G, Regnaut S and Goudet J. 2005. Detecting the number of clusters of individuals using the software structure: a simulation study. Molecular Ecology 14: 2611-2620.

Fufa M. 2013. Genetic Divergence in Ethiopian Coriander (Coriandrum sativum l.) Accessions. Adv. Crop Sci. Tech. $1: 116$.

Ghafoor A, Ahmad Z, Qureshi AS and Bashir M. 2002. Genetic relationship in Vigna mungo (L.) Hepper and V-radiata (L.) R. Wilczek based on morphological traits and SDS-PAGE. Euphytica 123 (3):367-378.

Jaccard P. 1987. Nouvelles recherces sur la distribution florale. Bull. Soc. Vaudoise Sci. Nat. 44, pp. 233-270.

Kan Y, İpek A. 2004. The yield and some characteristics of the chosen coriander (Coriandrum sativum L.) lines. Proceedings of the $\mathrm{Xl}$ th symposium on plant originated crude drugs Ankara, May 29-31, P.149-153 ISBN 975-94077-2-8.

Khurshid H, Rabbani MA. 2012. Comparison of electrophoretic protein profiles from seed of different oilseed brassica cultivars. Journal of Public Health and Biological Sciences. Vol. 1, No. 2, p.36-42. ISSN 2305-8668.
Laemmli UK. 1970. Cleavage of structural proteins during the assembly of the head of bacteriophage T4. Nature 227 (5259):680-685.

Lopez PA, Widrlechner MP, Simon PW, Rai S, Bailey TB, Gardner CA. 2007. Screening coriander gene pool for special use. In: Issues in new crops and new uses (Eds.; J. Janick and A. Whipkey). ASHS Press, Alexandria, VA. Pp. 280-283.

Lopez PA, Widrlechner MP, Simon PW, Rai S, Boylston TD, Isbell TA, Bailey TB, Gardner CA, Wilson LA. 2008. Assessing phenotypic, biochemical and molecular diversity in coriander (Coriandrum sativum L.) germplasm. Genet. Resour. Crop Evol. 55, 247-275.

Mengesha B, Alemaw G. 2010. Variability in Ethiopian coriander accessions for agronomic and quality traits. Afr. Crop Sci. J. 18: 43-49.

Özer S, Tümer E, Baloch FS, Karaköy T, Toklu F, Özkan H. 2012. Variation for nutritional and cooking properties among Turkish field pea landraces. J. Food Agric. Environ. 10, pp. 324-329.

Pareek G, Samaddar M and D'Silva P. 2011. Primary sequence that determines the functional overlap between mitochondrial heat shock protein $70 \mathrm{Ssc} 1$ and Ssc3 of Saccharomyces cerevisiae.J Biol Chem 286(21):19001-13.

PDRHM. 2007. Walnut: Junglans regia. In: PDR for herbal medicines (4. Edition), Montvale, NJ, Medical Economics Company. 881-882.

Purseglove JW, Brown EG, Green CL and Robbins SRJ. 1981. Spices. Vol. 2. Longman, New York. pp. 736-788.

Sammour RH. 2014. Cultivars Identification Based On Biochemical Markers. Research \& Reviews in BioSciences. Volume 8, Issue 9, Pages 347-358.

Singh SK, Kakani, RK, Meena RS, Pancholy A, Pathak R, Raturi, A. 2012. Studies on genetic divergence among Indian varieties of a spice herb, Coriandrum sativum. J. Environ. Biol. 33, 781789 (2012) ISSN: 0254-8704.

Szujkô-Lacza J. 1994. Architecture and inner structure of the Coriandrum sativum L. Akadémiai Kiadô, Budapest, Hungary.

Toklu F, Karaköy T, Haklı E, Bicer T, Brandolini A, Kilian B, Özkan H. 2008. Genetic variation among lentil (Lens culinaris Medik) landraces from Southeast Turkey Plant Breed. 128, pp. $178-186$. 